\title{
Conflict transformation and collaboration in developing social forestry in Flores, Indonesia
}

\section{Prudensius Maring ${ }^{1^{*} \mathbb{D}}$}

\section{AFILIATION \\ 1. Faculty of Communication Science, Budi Luhur \\ University, Jakarta, Indonesia. \\ * Correspondence: prudensius.maring@budiluhur. ac.id}

RECEIVED 2021-03-10

ACCEPTED 2021-11-25

COPYRIGHT @ 2022 by Forest and Society. This work is licensed under a Creative Commons Attribution 4.0 International License

\begin{abstract}
Social movements to realize forest tenure reforms have been ongoing since the 1970s, particularly through policies under the broad umbrella of social forestry. In Indonesia, social forestry programs are initiated by the government, communities, NGOs, academics, companies, and donors, and are based on specific socio-economic and ecological interests. Weak synergies, however between programmatic implementation and stakeholder interests, triggers various forest tenure conflicts. The research examines the complexity of these conflicts, namely focusing around the approaches to conflict transformation that can lead to collaboration in realizing forest sustainability that also support interests of people living in and around forests. I employed a qualitative approach by collecting data through in-depth interviews and participatory observations in Flores in 2017 and 2020. The results show that forest tenure conflicts have occurred since the 1970 s due to state forest territorialization. Conflicts culminated in the determination of state forest area boundaries through the 1984 state program entitled the "consensus-based forest land use planning" initiative. Until 2008, efforts to resolve conflicts by offering the community access rights through community forestry programs initiated by the government were rejected by NGOs and the local community. NGOs facilitated communities to demand the return of state forest land as customary forest. This conflict presented the opportunity to facilitate multi-stakeholder forestry programs through a conflict transformation approach by building long-term stakeholder collaboration. Since 2010, the collaboration between stakeholders took place through the community forest program. This study shows the need for more direct attention to studying conflict resolution under an integrated and longterm approach to conflict transformation and collaboration. Pragmatically, this study shows the importance of integrated social forestry policies that synergize various schemes initiated by stakeholders to realize forest sustainability and support local community interests.
\end{abstract}

\section{KEYWORDS}

Conflict; conflict transformation; collaboration; social forestry; Flores; Indonesia

\section{INTRODUCTION}

Social movements advocating for social forestry (SF), aligns with communitybased forest management $(\mathrm{CBFM})^{1}$ and forest tenure initiatives that have become popular on the global agenda for sustainability and human rights (Pambudi, 2020; Ravindranath et al., 2006; Rout, 2018; Ashri, 2019; Salam et al., 2006). The SF movement is not free from conflict of interests, however, due to the multiple parties

\footnotetext{
${ }^{1}$ In the current article, the concepts of CBFM and SF are written/mentioned jointly or separately depending on the elaborated contexts of space, time, and the particulars of the initiative. The mention of the SF/CBFM concept in the introduction is adjusted to reference the source being used. In the Indonesia case, in the period before 2015 the term CBFM was more widely used and after 2015 the more frequently used term was social forestry (SF). This is in line with the establishment of a policy on social forestry after 2015 as described in the introduction. In the description of the forest tenure conflict in the case study of this article in Sikka, since the 1990s the CBFM concept has been more popularly used by various stakeholders (NGOs, government, academics, and communities). This also changed with the onset of social forestry policy after 2015.
} 
involved (Fisher et al., 2019). In Indonesia, SF movements to place community as the subject of forest management were not necessarily accepted by those in support of state-based forest management. In contrast, NGO groups did not automatically accept community-based forest management programs and schemes coming from the government. The government's concern was often associated with demands to free state forest area lands from community interests in utilizing state forest lands, whereas civil society organizations' concerns were a means to push back against the strong government authority enclosing state-forest management programs or schemes. Such a state of affairs has, consequently, instigated disputes between communities, NGOs, companies, and government in several regions throughout Indonesia (KPA, 2020; Koning et al., 2008; Maring, 2013a; 2015; Prihatin and Wicaksono, 2020; Purnomo and Anand, 2014).

The social forestry movement in Indonesia began with the emergence of the forest for people concept during the world forest congress in 1978 (Fisher, et al, 2019; Zakaria et al, 2018). The SF/CBFM movement has been bolstered by involving various stakeholders such as NGOs, academics, governments, communities, companies, and donor organizations (Awang, 2006; Bong et al., 2019; Erbaugh, 2019; Fisher et al., 2019; Moeliono et al., 2017; Setiahadi et al., 2017; Suhardjito and Wulandari, 2019; Zakaria et al., 2018). In Indonesia, since the 1990s, these stakeholders have initiated variants of SF/CBFM approaches and policies in the form of forest village community development, intercropping programs, community forest systems, customary forests, and community forests. Since 2016, five schemes were developed under the social forestry policy (see the next section). Despite these various SF schemes having a similar vision of achieving socio-economic benefits of forests/forestry for the people, they remain burdened by conflicts among supporters of these SF/CBFM variants. Community Forestry (HKM) programs began in 1995 to open up the opportunity for communities to access forest management rights via legal-formal licensing mechanisms. However, HKM also opened up resistance from certain parties such as NGOs and community groups in the field and began promoting the development of other social forestry schemes. The HKM scheme was considered very much attached to government authority, although communities showed interest in the program given the prospects of limited tenure arrangements (Awang, 2006; Maring, 2010, 2015; Munggoro, 2002). ${ }^{2}$ Conflict and resistance in these cases have been documented, such as in Lampung, in Sikka of East Nusa Tenggara, and in Mataram of West Nusa Tenggara (Fisher et al., 2017; Maring, 2015; Mohamad et al, 2021; Nindyatmoko et al., 2020; Nurlia et al., 2020; Setiahadi et al., 2017).

An important phase of aligning the vision of government-led community forestry with community forestry initiated by NGOs and other actors began through the formulation of Law No. 41/1999 on Forestry and the formulation of Government Regulation No. 34/2002 concerning forest management and forest management plans. ${ }^{3}$ Throughout the development of SF/CBFM programs over time, certain NGOs and community groups have been cautious of formal schemes, and at times rejected government initiatives. Such a situation occurred in Sikka Regency at the onset of the

\footnotetext{
${ }^{2}$ Policies on HKM were amended since its enactment in 1995. In 2014, there were amendments through the Regulation of the Ministry of Forestry of the Republic of Indonesia Number: P.88/Menhut-II/2014 on Community Forestry.

${ }^{3}$ See Governmental Regulation No. 34/2002 on Forest Administration and the Formulation of Plans for Forest Management, Forest Utilization, and the Use of the Forest Estate, which was then revised.
}

Maring (2022) 
reform era in 1998, and disputes lasted until 2008 between the government, the community, and NGOs. NGOs that were active in CBFM/SF in the area assisted the community to demand taking back state forest land from the government and reterritorializing land as community owned through government mechanisms for customary forests. The regional forestry office also facilitated the community to support the HKM program. Conflict resolution efforts carried out since the 1990s had failed to address disagreements between the community and the forestry apparatus. Meanwhile, efforts to build collaboration between communities, government, and NGOs faced challenges and requires a more persuasive and long-term approach (Maring, 2010, 2015; Munggoro, 2002; Royo et al., 2010).

Since 2010, the idea of social forestry had begun to gain traction and popularity. This, in part, was due to the political momentum of the 2010-2014 Mid Term National Development Plan (Rencana Pembangunan Jangka Menengah Nasional), which at the time politically secured a substantial position for social forestry policy with a target designation area of 1 million hectares explicitly included in the national plan. Subsequently, in the 2015-2019 Mid Term National Development Plan, ${ }^{4}$ social forestry was expanded in the national plan with a targeted achievement of approximately 12.7 million hectares of land. This political momentum was then followed by a policy reinforcing the organizational structure of social forestry ${ }^{5}$ establishment of the working group on social forestry, ${ }^{6}$ and regulation of social forestry permits. The establishment of social forestry policy also integrated five social forestry schemes, namely: Community Forest (Hutan Kemasyarakatan - HKM), Village Forest (Hutan Desa - HD), Community Plantation Forest (Hutan Tanaman Rakyat - HTR), Customary Forest (Hutan Adat - HA), and Forestry Partnership (Kemitraan Kehutanan - KH) ${ }^{7}$ (Fisher et al., 2019; Moeliono et al., 2017; Zakaria et al., 2018). Several critical perspectives of social forestry also highlight intended consequences that arise due to obstacles in licensing administrative procedures, poor land administration, competition of economic interests among local actors, weak facilitation support, and dilemmas in the delegation of authority between central and regional governments (Fisher et al., 2018; Prihatin and Wicaksono, 2020; Zakaria et al., 2018).

The transformation of social forestry since its inception as a common vision for community-based forest management led to the emergence of several initiatives by multiple stakeholders. Nonetheless, their common vision is still constrained by conflict of interests between the government as the formal authority and civil society groups fighting for community interests. This is observed from the conflict between schemes that emerged as government programs and those initiated by NGOs along with the community. Conflict impedes implementation of social forestry schemes and requires a conflict transformation approach and collaboration of stakeholders in the field (Adu et al., 2015; Chaudhary et al., 2015; Kane et al., 2018; Maring, 2013; Stern and Coleman, 2015). The initiation of social forestry policy, which is oriented toward reserving targeted areas of social forestry and integrating all community-based forest

\footnotetext{
${ }^{4}$ The 2015-2019 National Mid Term Development Plan was established through Presidential Regulation No. 2/2015 on January $8^{\text {th }}, 2015$.

${ }^{5}$ See Presidential Regulation No. 16/2015 on the Ministry of Environment and Forestry.

${ }^{6}$ Regulation of the Director General of Social Forestry and Environmental Partnership No. P.14/2016 on the Working Group on Social Forestry Acceleration.

${ }^{7}$ See Regulation of the Minister of Environment and Forestry Number: P.83/MENLHK/SETJEN/KUM.1/10/2016 on Social Forestry.
}

Maring (2022) 
management schemes, has provided a key focus for the social forestry movement. One of their main interests is resolving forest tenure conflict.

The description above raises the following research question, namely in the midst of the complexity of conflict of interest among stakeholders, how can approaches to transformation of conflict help preserve forest and community interests? Social forestry as a movement for land rights and sustainability is not free from conflicts. It is not enough to only apply a conflict resolution approach. Social forestry must encourage a conflict transformation approach through a collaborative process with integrated policy support that accommodates all social forestry schemes and encourages meaningful activities at the field level. The structure of this article presents a theoretical framework in section 2. It is followed by a results section that focuses on three elements, namely: First, the reality and complexity of conflict. Second, the conflict transformation phase, which unveils conflicts among parties in support of the CBFM/SF agenda. Third, collaboration to strengthen community interests through HKM. The discussion section explains how various conflict transformation approaches can be steered toward collaboration through policy support in order to strengthen community interests in the social forestry movement. The main concepts used in the analysis are social forestry, conflict transformation, and collaboration.

\section{THEORETICAL FRAMEWORK: SOCIAL FORESTRY, CONFLICT TRANSFORMATION, AND COLLABORATION}

The concept of social forestry was initially introduced by Westoby (1968) as a forestry related activity that ensures benefits of forestry products for the community (Das, 2015; Hakim, 2010; Tajuddin et al., 2019). Along the same lines, the concept of social forestry is also understood as a form of engagement of the public's influence and role in decision making processes of forest management, the implementation of forest management, the arrangement of community access and forest management products for the community (Maryudi et al., 2012; Tajuddin et al., 2019). In terms of legal-formal regulations, social forestry in Indonesia provides the opportunity for local communities or customary law communities to become a key actor in improving their welfare, ensuring balance between the environment and socio-cultural dynamics through various programs/schemes such as village forests, community forests, community plantation forests, people's forests, customary forests, and forestry partnerships. These social forestry programs/schemes are implemented through a sustainable forest management system in state forest areas or logging concession areas, and customary forest areas (Tajuddin et al., 2019).

In its current development, the concept of social forestry contains perspectives and viewpoints of various practical benefits. Generally speaking, there are four categories of supporters/actors of social forestry indicated by their understanding and implementation of social forestry, which include: First, the category that emphasizes the social aspect, wherein the community's rights and participation are considered as most crucial in social forestry. Second, emphasis is placed on the aspect of legality, wherein obedience to laws and rules is given significant attention in social forestry. Third, priority in the aspect of conservation, in which aspects of forest sustainability and biodiversity become a major concern in social forestry. Fourth, emphasis is placed on dimensions of development and welfare, wherein the economic aspect for the interest of the government and the people living in and around the forest is a major consideration in social forestry (Fisher et al., 2019). 
The above categorization, which is based on the understanding and implementation of social forestry, indicates the various concerns of social forestry supporters/actors, namely: the aspect of community's interest, the conservation aspect, the aspect of legality, and the economic aspect (Fisher et al., 2019). In general, the parties that contribute to social forestry include government officials-bureaucrats, non-government organizations, scholars and researchers, the community, and entrepreneurs with their respective differing interests (Yeni, et al., 2018; Wahyu, et al., 2019). The differing interests of parties that remain unaccommodated may trigger resistance and open conflict. Communities may resist by engaging in forest utilization activities secretly, covertly, or by avoiding forestry apparatus (Scott, 1985; Scott, 1992; Maring, 2013a). Open conflict forces the parties to confront one another directly in order to demand/maintain their interests, which can be achieved through various means, such as land occupation (commonly practiced by communities), acts of violence (carried out among conflicting parties), repressive operations (commonly executed by forestry apparatus), protests/demonstrations (commonly held by communities and NGOs), that may lead to the destruction of forest resources and even cause loss of life (Jackson, 1993; KPA, 2020; Wulan, et al., 2004).

Efforts to resolve conflict over forest resources can be undertaken by using conflict resolution or conflict transformation approaches. The conflict resolution approach can be applied as an effort to resolve ongoing conflict events that require a resolution. Conflict resolution is aimed at controlling, stopping, and preventing the spread of an occurring conflict (Morrill and Rudes, 2014; Wang and Wu, 2020). However, in relation to the objectives of social forestry, which are forest preservation and sustainable community interests, a conflict transformation approach is, thus, necessary. Conflict transformation is defined as a process that positions the parties involved in active conflict to undergo mutual learning and creative means for resolving the conflict in a sustainable manner. Conflict transformation is defined as an opportunity to create social change constructively for the sake of lessening violence, enhancing justice, interacting directly in social reality, and responding to issues in human relations. The conflict resolution process through a conflict transformation approach opens up new perspectives to carry out sustainable social change. Conflict transformation approaches are initiated by opening up conflicting parties' insights to reflect and learn to look at their conflict experience and find a long term mutual solution (Kane et al., 2018; Maring, 2013).

Conflict transformation approaches demand collaboration by involving all relevant parties in forest management. Conceptually speaking, collaboration is defined as a process in which two or more individuals are actively involved in thinking, planning, deciding, and cooperating, as a manifestation of co-creation process and mutual understanding to achieve a jointly constructed particular goal. In the context of forest tenure, collaboration is defined as a process in which stakeholders actively engage in the following efforts: 1) articulate interests; 2) discuss differences; 3) construct common interests; 4) formulate common goals and strategies; 5) determine control mechanism to achieve common goals (Chaudhary et al., 2015; Maring, 2010).

Collaboration is also defined as a form of partnership, namely "a relationship involving the sharing of power, work, support and or information with others for achievement of joint goals and/or mutual benefits" (Kernaghan 1993 as cited in Suporahardjo, 2005). As a process, collaborative sustainable forest management comprises several key elements that need to be conducted. They are: 1) joint analysis 
of the situation; 2) negotiation and agreement among stakeholders; 3) development of change capacity; 4) partnership and alliance in implementation; 5) creation and maintenance of the learning process; and 6) creation and promotion of a mechanism to carry out conflict transformation (Maring, 2013; Suporahardjo, 2005).

\section{MATERIALS AND METHODS}

The current study employed a qualitative approach. The main research data is in the form of primary data obtained through interviews and observations (Almalki, 2016; Archibald et al., 2015; Creswell, 2013; Nassaji, 2015). Secondary data were acquired by searching for documents and mass media publications at the local level. In-depth interview methods were used to collect data about the history of forest tenure, occurring conflicts and collaborations, social relations among residents, NGOs, and forestry apparatus. Forest management data were obtained via interview and participatory observations. The observation method was used not only for collecting new data, but also as a triangulation method to confirm data from the interviews.

Field studies were conducted in several villages, in this article referred to as V1, V2, V3, V4, and V5 in Sikka Regency, Flores, East Nusa Tenggara. The informants in the study consisted of community members, village administrators, NGO activists, and forestry officers. The total number of informants was 17 people. Data were also obtained from regional forestry officers, who were in the Technical Implementation Unit - Forest Management Unit (Unit Pelaksana Teknis Kesatuan Pengelolaan Hutan - UPT$\mathrm{KPH}$ ) and, previously, in the regional forestry office. Some informants were from NGOs that actively facilitated and assisted the community in the process of preparing HKM licensing and strengthening the community's institutional capacity. In order to acquire data on the advocacy process during the conflict period that had ensued since 1990, some of the informants were selected out of NGO activists who still actively provide the community with assistance, and one has even become a local legislative member. The informants were selected in accordance with the data requirement.

The community living in and around the forest area, which is called Noge forest in this article, are indigenous inhabitants spread out in 23 villages of 4 districts. In 2019, the population in the four districts around Noge forest was 75,318 people out of the total population of the regency, which was 321,765 people (Anonymous, 2020). Most of the villagers work as dry land farmers who own land for planting coarse grains, pulses, roots, and tubers (CGPRT - palawija), and annuals. The community there has a strong interaction with the Noge forest area and they have a local wisdom system regulating areas that are permissible for cultivation activities (opi dun kare taden) and areas that must be protected (opidun kare dunan). Customary figures, customary institutions, and customary systems still maintain their roles along with the village administration. The traditional management system continues to be under pressure due to the limitation of land to support their agriculture, plantation, and livestock related activities around the forest area. There are some villagers, in limited numbers, who work as part-time fisherfolk at villages located along the North and South coast of the Noge forest area (Maring, 2010, 2015).

The sources of data used in the article are from field studies carried out for 1 month in 2017 and 1 month in 2020 on community engagement in forest management. Some sources were obtained from past research, namely in 2007 on forest tenure conflict. The researcher was also directly involved as a member of the facilitator team in facilitating a conflict resolution of forest tenure involving the regional government, 
the community, and NGO at the study site throughout the 2000-2006 period. Data collection was carried out at the kampong/village, district, and capital of regency levels with the kampong/village as the starting point.

Data analysis was initially carried out by organizing field notes and classifying data into three themes/section: First, the reality and complexity of conflict. Second, the conflict transformation phase, which unveiled the conflict among the parties in support of the CBFM/SF agenda. Third, the collaboration phase to strengthen the community's interest through HKM. The main issues and key concepts in the analysis are conflict transformation, collaboration, communication of interests, and integrated policy. The results provide a description of how conflict transformation can be steered toward collaboration through policy support in order to strengthen community interest in the social forestry movement.

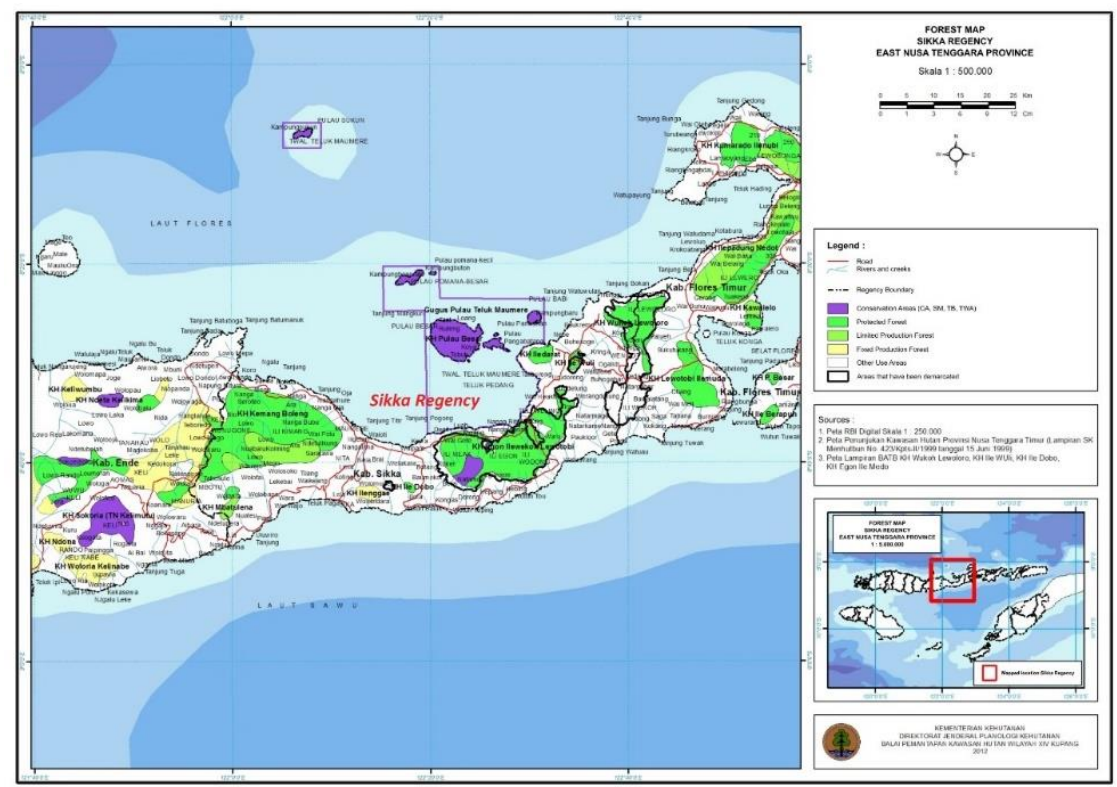

Figure 1. Research site in Sikka Regency, Flores, East Nusa Tenggara, Indonesia (note: Legend edited by the author).

\section{RESULTS}

\subsection{The reality and complexity of conflict}

The community alluded to in this research is part of 23 villages around the Noge forest area. The source of livelihood for the majority of residents around the forest area includes dry land agriculture, especially in the form of cultivation and annual crops. The Noge forest area has two versions of boundaries, namely the 1932 boundary set during the Dutch colonial era and the 1984 boundary set by the Ministry of Forestry of the Republic of Indonesia through the Forest Use Agreement (TGHK) program. These two versions of boundary delineation are the source of conflicts between communities around the Noge forest and forestry officials. According to the community, the 
determination of forest area boundaries in 1932 (during the Dutch colonial government) showed the government's intention to acknowledge the existence of indigenous peoples around the Noge forest. The community is involved through deliberation so that it does not trigger rejection from the community. The community was not involved in the process of demarcating the boundaries in 1984. The crucial aspect about the designation of the TGHK forest area was that it took place partially on the community's land, which was established based on the 1932 boundary. This is evident in total area differences, namely the 1932 boundary version included 8,100 hectares while the 1984 TGHK version expanded to 19,456 hectares.

According to local informants, community evictions from the Noge forest had been ongoing since 1970. Forestry officers evicted residents from the forest area by destroying houses and driving away livestock belonging to residents. The actions of these officials were so unsettling for the community that residents left their villages. The community moved their villages outside the forest area but in 1971, in several places, the forestry apparatus more aggressively used violence in the form of burning people's houses, seizing agricultural tools, and culling livestock. As a result, residents left the village and fled again to surrounding areas. Various pressures from forestry officials were met with resistance from the community. In 1976 a forestry officer with initials SK was killed by residents. In 1978 an officer named TH was chased by the community in the $\mathrm{V} 2$ village.

As maps were redrawn in 1984, the community began to openly resist by occupying areas, holding forestry officials in custody, conducting demonstrations, and incidents of physical altercations. Community resistance was blocked by the government on the pretext of legal provisions and a security approach. Then in 1990, a citizen was arrested and imprisoned. A similar incident occurred again in 2002 when 9 residents were apprehended and jailed for 10 months on charges of encroaching state forest areas. This incident sparked open resistance through demonstrations and confinement of forestry officers by the community in V4 village. In 2002, groups of forestry officers from the national level and provincial lelves were taken hostage by the community in V4 village. The group was only released after negotiations and the deployment of police officers.

Apart from the vertical conflicts that took place between the community and forestry officials, since 1984 an increasing number of horizontal conflicts have taken place between the villagers of V2 and the people who came from SS village. The residents of SS village occupied land (at the DN location) in the Noge forest area. V2 villagers are indigenous people who traditionally control forest land in DN locations. Residents from SS village entered the DN site in 1984 through the facilitation of forestry field officers. The inhabitants of the SS village were involved as laborers in the reforestation project financed by the forestry department whose implementation in the field was carried out by the provincial and district forestry offices. Various attempts were made by the villagers of $V 2$ to resolve this case but were unsuccessful. In 1997 the villagers of V2 faced the people from SS village directly. This incident was the largest horizontal conflict between the villagers of V2 and the villagers from SS village who occupied the DN location. About 15 residents of the SS village were involved in physical altercations with villagers of $\mathrm{V} 2$. The series of horizontal conflicts between villagers in $\mathrm{V} 2$ and villagers of SS is shown in the following table. 
Table 1. Event of horizontal conflicts between communities

\begin{tabular}{|c|c|}
\hline Time & Event of Conflict \\
\hline 1984 & $\begin{array}{l}\text { For the first time, people from SS village entered the DN location in a } \\
\text { forest area through the facilitation of forestry officers to become } \\
\text { workers for a reforestation project. }\end{array}$ \\
\hline April $5^{\text {th }}, 1989$ & $\begin{array}{l}\text { Villagers V2 urged SS residents to leave the DN location. With this } \\
\text { pressure, about } 55 \text { SS residents made a statement that they were } \\
\text { willing to leave the DN location. }\end{array}$ \\
\hline 1993 & $\begin{array}{l}\text { V2 residents blocked the entrance to the DN location which caused } \\
\text { tension between residents for } 1 \text { month. The police helped maintain } \\
\text { security in the village. }\end{array}$ \\
\hline 1997 & $\begin{array}{l}\text { V2 residents intercepted } 15 \text { SS residents in the forest area. This } \\
\text { resulted in physical altercations. This problem was reported to the } \\
\text { police. }\end{array}$ \\
\hline 1998 & $\begin{array}{l}\text { A fight broke out between a resident of V2 and a resident of SS. The } \\
\text { instigators were SS residents. }\end{array}$ \\
\hline 1998 & $\begin{array}{l}\text { An SS resident was killed in a gambling arena. This incident was } \\
\text { associated with the conflict between V2 and SS residents. }\end{array}$ \\
\hline March $27^{\text {th }}, 2000$ & $\begin{array}{l}\text { V2 residents demanded a firm stance from the government. The letter } \\
\text { was sent to the district government, sub-district government, and the } \\
\text { village government. }\end{array}$ \\
\hline Augi & SS residents demonstrated at the Loca \\
\hline $23^{\text {rd }}$, & $\begin{array}{l}\text { Perwakilan Rakyat Daerah) office and the Sikka Regent's office to } \\
\text { oppose the actions of V2 residents. }\end{array}$ \\
\hline September $5^{\text {th }}, 2000$ & $\begin{array}{l}\text { The Regent of Sikka invited V } 2 \text { and SS residents to mediate and resolve } \\
\text { the conflict. A team was formed to resolve the conflict. }\end{array}$ \\
\hline 2005 & residents cut off the water pipe that flows to V2 village \\
\hline
\end{tabular}
Source: Results of primary data processing, Maring (2010).

In response to the conflicts between communities and forestry officials, and conflicts between communities without clear resolution, advocacy has been carried out since the mid-1990s by NGOs (at the national and regional/local levels). These conflict resolution initiatives took place through the emergence of the CBFM and SF social movements. Several local NGOs (such as LBH-N and YBF) facilitated Indigenous community groups around the Noge forest to claim Indigenous Peoples' rights to state forest areas. These NGOs operating at the local level have networks with NGOs operating at the national level such as AMAN (Aliansi Masyarakat Adat Nusantara), KPSHK (Konsorsium Pengembangan Sistem Hutan Kerakyatan), and FKKM (Forum Komunikasi Kehutanan Masyarakat). The agenda that was pushed by NGOs at the local level was linked to the struggle of Indigenous Peoples around the Noge forest to demand a shift in the boundaries of state forest areas from the TGHK version of the 1984 boundary to the boundary version in 1932. The dynamics that occurred from the mid1990 s to 2006 are discussed in the following sub-section regarding conflict transformation as an effort to synergize the SF/CBFM scheme.

\subsection{Conflict transformation as efforts to synergize CBFM/SF schemes}

This sub-section explains the empirical evidence about the advocacy agenda initiated by NGOs through the customary forest system, which faced the governmentinitiated program known as the HKM program. The momentum of the territorialization of state forest estates through the TGHK program in 1984 undermined the longstanding forest tenure system practiced by the community living around the Noge forest area. 
Since the Noge forest was designated as a state forest area by the Dutch colonial government in 1932, the community had control over certain lands of the Noge forest area through conducting cultivation activities, planting of annual crops, and establishment of settlements. The community planted the forest area all the way to the Dolo-Dala border, which is known as the boundary of the protected forest area during the period of Dutch colonial rule. Attempts to expand the state forest area during Indonesia's period of independence using a tactic of making roads to control forests, commonly called "jalan kuda" (horse paths) had continued since the 1950s until the early 1980s (Maring, 2010, 2015).

The disagreement between the advocacy agenda initiated by NGOs and the government through the HKM program had led to a multiparty conflict concerning the visionary-conceptual level at the top, which consequently had an impact on the community. At the conceptual level, CBFM/SF is a forest management agenda that operates inclusively by involving various stakeholders such as NGOs, academics, governments, communities, researchers, companies, and donor organizations. However, at the ground level, from the beginning of the 1990s up to 2008, CBFM had been situated as an agenda that tended to represent the NGO movements with their agenda to advocate for the community-based forest system and customary forest. Efforts to push the CBFM agenda by forming the CBFM Forum involved all stakeholders but ran into difficulties because of the impression that CBFM is identical to the agenda of community-based forest system and customary forest. The regional forestry office, as the regional government's representative, felt uncomfortable being a part of the CBFM Forum. The NGO's strategy of electing the Head of the Regional Forestry Office as the coordinator of the CBFM Forum did not last long since the regional forestry office stepped down on account of their discomfort with the agenda of community forest and customary forest (Maring, 2010).

Differences in stakeholders' understanding and acceptance of HKM and the agenda it promoted through the community-based forest system and customary forest carried over to actions on the field, such as preparation of community groups and preparation of technical requirements for the HKM program. The group of NGOs such as LBHN and YBF that supported CBFM had prepared the community to support the agenda being championed by NGOs. Conversely, the regional forestry office facilitated a group of people in a certain village through the HKM scheme. The discord among stakeholders in the case of Noge forest land tenure is apparent through the efforts undertaken by the regional forestry office to realize the HKM scheme and the efforts conducted by NGOs to accomplish the agenda of the community forest and customary forest since the early 1990s. Initially, the community-based forestry system was expected to accommodate demands for taking over state forest lands and turn them into the community's right of ownership. However, since the early 2000s, along with the waning of the opportunity to claim right of ownership over state forest lands through the community-based forest system scheme, the struggle continued by making use of the customary forest system. ${ }^{8}$ The customary forest scheme was considered able to obtain right of ownership over land by moving the state forest area from the 1984 TGHK border to the 1932 Dolo-Dala border. NGOs continued to assist the community (in village V4) by mapping out the boundaries of the customary area and revitalizing

\footnotetext{
${ }^{8}$ NGOs considered the shift as a sense of willingness and leniency on their part to negotiate with the government.
} 
customary institutions to prepare for claiming state forest area land management via the customary forest system. ${ }^{9}$

On the other hand, the regional forestry office actively facilitated community members in several villages (in V2 village) to realize the HKM scheme. The forestry office stated that HKM is a product of government policy based on land management rights that must be realized. The disagreement between the NGO group and the regional forestry office had impacted the community. People of V2 who were facilitated by the regional forestry office from the start were ignored by NGOs in continuing their agenda of struggle in the Noge forest area. Nonetheless, they continued to side with the regional forestry office on account of continued facilitation by the government. They considered that the NGOs would not be able to guarantee their struggle to drive cultivators from outside of the village away from entering the forest in their area through the reforestation project. ${ }^{10}$

Facilitation given for HKM implementation had continued since 2000 in V2. The community accepted the HKM program because they considered that HKM is one of the strategies employed to maintain land tenure and fight for certainty of management rights over state forest areas. They have, for a long period of time, been controlling the land, cultivating, and living in the forest area. They need certainty concerning concession rights through the HKM permit. The public outreach carried out by the regional forestry office in V2 went smoothly. Although the people there accepted HKM, they remained critical of the government and forestry apparatuses in the field. In numerous meetings with the regional government, the people of V 2 village showed a firm attitude and criticized the behavior of government apparatus that opposed their expectations. The people requested that the government consistently provide facilitation and protect residents who have been living in the forest area for decades (Maring, 2010; 2015). ${ }^{11}$

Perception on advantages and disadvantages of HKM and customary forest transpiring between the related parties such as NGOs, government, and community had affected implementation at the ground level. The stance $V 2$ villagers who supported the HKM program was giving support to the regional forestry office to implement HKM. The villagers were willing to have their cultivation area made into a site for implementing HKM. Their stance had consequently garnered a negative response from NGOs that were proponents of the customary forest scheme. From the beginning the NGO group had intended to facilitate V2 villagers' needs, but over time, the villagers' stance was considered counterproductive to the direction of the NGO movement. The NGO group considered community figures of V2 village as being supportive of all the regional forestry office's programs. Such dynamics was then carried over into the multistakeholder forum. There was the impression that community figures of V2 village constantly presented community aspirations supporting the regional forestry office. While, in contrast, community figures from villages assisted by NGOs (in village V4) presented community aspirations supporting the demand to hand over state forest area land to the people (Maring, 2010, 2015).

Different views between the government and NGOs above hindered discussions

\footnotetext{
${ }^{9}$ Also see the report of LBH-Nusra (2004) on forest conflict resolution through a multi-stakeholder approach in Sikka Regency.

${ }^{10}$ Also see Virama-Karya's report (2001) on identification of potential HKM and community's preparedness.

${ }^{11}$ Also see the report by the Soil Conservation and Land Rehabilitation Board (Balai Rehabilitasi Lahan dan Konservasi Tanah-BRLKT) of Kupang that facilitated the multi-stakeholders workshop in 2001.
}

Maring (2022) 
on implementation of HKM and customary forest. The NGOs pointed out that the slow process to facilitate the public's interest and rights over the forest persisted on account of the regional forestry office's weak capacity in responding to new ideas outside of the HKM scheme. Meanwhile, the regional forestry office constantly rejected the NGO's agenda without offering any clear alternatives and reasoning. Instead, the regional forestry office felt entitled to implement HKM as a government policy. The office pointed out that the implementation scheme in the NGOs' agenda is unclear and that the process implemented by the NGOs was not coordinated with the regional forestry office, which claimed authority over state forest areas. The pros and cons between the regional forestry office and the NGOs also led to implications at the community level. Communications between community members who were for and against the two schemes offered were not well aligned. It was apparent that both the government and the NGOs maintained their respective interests and caused discord at the community level.

The description above shows that debates at the strategic/conceptual level of HKM, community-based forest system, and customary forest ultimately diminished the community's trust in the government and NGOs in the field. The community assisted by NGOs were not enthusiastic in accepting the government's offer to resolve border issues through the HKM program, despite HKM offering a scheme of land management rights. Conversely, community groups that enthusiastically supported SHK and HA from the onset began to be disheartened. The community's awareness of the prolonged conflict between HKM, SHK, and HA boiled down to the community protesting against the role of the NGOs and the government.

In the regional level multi-stakeholders forestry forum in 2001, the community demanded the regional government and the NGOs to maintain a fair and honest role in facilitating the implementation of community based forest management. ${ }^{12}$ The multistakeholder forum was, consequently, a product of the conflict transformation dynamics through collaboration among stakeholders to synergize CBFM/SF agendas throughout the 2000-2006 period. The process of conflict transformation was supported by the Multistakeholder Forestry Progamme (MFP), which was a collaborative program of the Indonesian Government and the UK Government. Intensive facilitation had encouraged the parties involved to understand their respective interests. Various methods helped in the process included a series of workshops on aligning perceptions, capacity building, and exchange of joint learning. Processes of conflict transformation were also supported by a conflict mediation team (consisting of academics, central forestry officials, NGO activists, and researchers). The support of donor organizations with the vision of promoting the democratization of forest management in Indonesia through multi-stakeholder approaches was a strategic momentum that unified differing perspectives and transformed the horizontal conflict that had occurred since 1984 (Royo et al., 2010; Fahmi et al., 2003). ${ }^{13}$

At an early stage, the NGO group was cautious of the multi-stakeholder idea promoted by donor organizations through a bilateral interstate/government cooperation. The NGO group was also suspicious of the multi-stakeholder process as an

\footnotetext{
${ }^{12}$ Also see the report by the conflict resolution team in 2002, which was done by Mulyana et al. (2002) and LBH-Nusra (2004).

${ }^{13}$ The initiative was implemented through the Multistakeholders Forestry Progamme (MFP) as a collaborative program of the Indonesian Government and the UK Government.
}

Maring (2022) 
attempt or tactic to stifle the outspoken voices expressed by the community and NGOs, and that it would reinforce government centralization instead ${ }^{14}$. In its development, the NGO group saw an opportunity to carry out ecological interventions through the multistakeholder forestry process. The multi-stakeholder agenda was considered beneficial to the NGO group's advocacy interests in terms of strengthening environmental sustainability. The NGO group had, subsequently, designed their endeavor to realize the community-based forest management scheme by placing the government and the community as two equal parties when conducting negotiations and establishing new agreements in forest management.

\subsection{Collaboration to realize community interests and forest sustainability outcomes through HKM}

The description above shows that the conflict transformation phase at the level of synchronizing CBFM/SF vision-strategy led to the inception of the Multi-Stakeholder Forestry Forum. Since the end of 2008, facilitation on the implementation of HKM had begun intensively. The regional forestry office gained support from the Ministry of Forestry to disseminate information about HKM, strengthen community institutions, and ensuring the areas were ready for HKM. The change in facilitation model applied in the field was affected by numerous aspects. Among them included a change in local political situations, growing support by local and national level NGOs, change in activities of NGO actors at the local level, consistency in facilitation provided by forestry institutions, policy support by the central government, and the role of Multistakeholders Forestry Progamme (MFP) as a collaborative program of the Indonesian Government and the UK Government. ${ }^{15}$ The process of reserving HKM areas, which had been carried out since 2010 had indirectly led the stakeholders to parties undertaking activities at the field level, such as land mapping and HKM community group preparation. The HKM policy provided the regional government its authority and used it to mobilize the facilitation process in the field. The Sikka Regional Government, with the support of other stakeholders initiated Regional Regulation No. 3/2014 on Community Forest Management. The Regional Regulation regulates the permit for community forest management (HKM) for the community around the forest area (Yanto, 2017). ${ }^{16}$

Synergy between the community and other stakeholders were conducted by utilizing the community's enthusiasm for collaboration, and local knowledge became explicitly included as an important part of social forestry goals that needed to be accomplished by all parties (Lee et al., 2017). As it happened at the study site, the community, the government, and the NGOs eventually considered HKM as an entry point to resolve the open conflict that had previously led to demonstrations and land occupation. The forestry apparatus assisted the community in providing understanding of HKM as a policy that affords management rights to the community. Efforts to share understanding about the ecological function of the forest area were always counterbalanced with efforts to raise the community's economic conditions. The

\footnotetext{
${ }^{14}$ In reality, the process had strengthened the position of the community in their negotiations with the government instead.

${ }^{15}$ One of the exit strategies of Multi-Stakeholders Forestry Programme was to establish a fund raising organization based in Nusa Tenggara and provide support by multi-stakeholder forestry facilitators.

${ }^{16}$ This regional regulation no longer applies since administration of the forest had been transferred to the provincial government, as stated by an NGO activist, JB (12 September 2020).
}

Maring (2022) 
forestry officers were aware that before the advent of HKM, the community had already engaged in cultivation activities in forest areas, thereby requiring them to employ a persuasive approach. The government also noticed other benefits from HKM, which is to prevent illegal logging and illegal activities in forest areas that officers find difficult to control. The forestry apparatus used caution due to the background of conflict (Yanto, 2017).

The community's acceptance of HKM had become more expansive. People living in 23 villages around the Noge forest area came to accept HKM as a way to improve their income. According to the community, although many sacrifices were made during the struggle in moving the forest area boundary, they eventually accepted the HKM program. Based on such long experiences of conflict, the community gladly welcomed the facilitation process given by the forestry institutions through the Technical Implementing Unit - Forest Management Unit (Unit Pelaksana Teknis Kesatuan Pengelolaan Hutan) and the support of NGOs. Since 2010, community groups began to offer the HKM proposal and by 2012 some community groups began receiving Commercial Community Forest Utilization Permit (Izin Usaha Pemanfaat Hutan Kemasyarakatan). In 2012, the community in V1 received their HKM Commercial Utilization Permit for an area of 346.88 hectares. The permit is considered as the result of a long struggle mired by conflict. Similar processes and results were also witnessed in several other villages. As of 2019, as many as 12,621.83 hectares of land had been granted HKM Commercial Utilization Permits by involving 3,526 heads of household through 23 customary farmer groups (Rosary, 2017). The government views HKM as an entry point for resolving protracted conflicts. As stated by the forestry apparatus, BHS:

"HKM is a solution to eliminating illegal logging and other illegal activities. Through IUP-HKM people can get legal certainty to manage land".

The conflict transformation process in the 2000-2008 period also led to changes in the strategy employed by NGOs at the local level. NGO activists who still actively provided assistance to the community or those who became local legislative members and were active in other fields also supported the HKM scheme as an effort to resolve prolonged conflicts. As stated by RA, an NGO activist who during 2000-2010 had rejected the HKM scheme: "The most crucial matter is that the community of forest farmers obtain their land management rights and solid legal standing." The NGOs' change of position enabled the intervention of the HKM program into villages around the Noge forest area. This change stood in stark contrast with the pre-2008 condition in which the NGOs sternly took a stance of pushing the agenda to demand the reinstatement of community ownership rights over forest land areas. The change of the NGO's position was, undoubtedly, inseparable from the long process of conflict transformation, which had begun since the start of the reform era until 2008, through the spirit of collaboration and the multi-stakeholder model. ${ }^{17}$

At the policy level, the changing stance and willingness to accept the HKM program, was also correlated with the national change in policy. In 2010, the Ministry of Forestry established the reserve for HKM areas in Sikka Regency totalling 16,755 hectares..$^{18}$ As of 2019 , permits for the utilization of forest areas by the community

\footnotetext{
${ }^{17}$ Also see: Maring, 2010; Rosary, 2017.

${ }^{18}$ The HKM area was established in the Decree of the Minister of Forestry of the Republic of Indonesia No. 388/Menhut-II/2010 on Reserve Area for HKM Management in the Egon Illimedo and Wuko Lewoloro Forest Area of 16,755 Hectares.
}

Maring (2022) 
through the HKM scheme in Sikka Regency had reached 12,621.83 hectares. Such achievements were in line with the size of the forest area in Sikka Regency, which is $38,442.43$ hectares. The achieved target of HKM area in Sikka Regency was defined and implemented in line with the preparedness of the community, land mapping, and administrative requirements for HKM permits. (ASFN, 2014; Rosary, 2017). Support in the HKM program facilitation had long been awaited by the community living around the forest area since most of the villages in East Nusa Tenggara are located around the state forest area. In East Nusa Tenggara Province, approximately $70 \%$ of villages are situated around the forest area (Octavia, 2019). That figure is in line with the national figure, because in 2014 around 20,000 villages are located in and around the forest and approximately 8.6 million households live around the forest (Zakaria et al., 2018).

The community admitted that their activities in the forest area are currently much more comfortable due to the existing legal certainty provided by the HKM commercial utilization permit. The plants cultivated by the community, generally include two categories, namely seasonal plants and longer term cultivation. Types of seasonal plants include rice (Oryza sativa L.), corn (Zea mays L.), cassava (Manihot esculenta), sweet potato (Ipomoea batatas), and taro (Colocasia esculenta). Meanwhile, the annual plants they cultivate include clove (Syzygium aromaticum), cacao (Theobroma cacao L.), cashew (Anacardium occidentale), coffee (Coffea sp), and candlenut (Aleurites moluccanus). Annuals have not been cultivated by the community around the Noge forest area for quite some time, including in their own lands outside of the state forest area. Some of the annuals have borne fruits such as cloves, cacao, cashew, and coffee. According to the community, they are beginning to reap benefits as seasonal and annual plants have started to be harvested. Household needs can be fulfilled from the crop yield in the forest area. Rice and corn yields as a source of food are available from a single planting season so the community does not buy at the market, as is the case with vegetables and tubers.

Currently, support from stakeholders, such as local NGOs (Sandi-Florata and Wahana Tani Mandiri) and forestry service officials, is focused on implementing activities at the field level. The local NGOs support the process of strengthening social institutions to obtain HKM permits. Several capacity building activities for farmers such as forest management, cultivation, agro-product processing, business analysis, and product marketing are carried out directly in villages with financial support form donor organizations that have facilitated in the conflict transformation and HKM program in the regency since the year 2000. Several NGOs have continued to coordinate and provide facilitation to central and provincial level forestry institutions with donor support. The forestry research and development unit conducted an analysis of HKM area potentials and transfer of technology for nurseries, seedbeds, organic fertilizers, processing and packaging of candlenut oil, candle-making using beeswax from honeybees (Apis), and postharvest processing of betel nut (Areca catechu). ${ }^{19}$

The regional government provides continuing support. Nonetheless, not all processes run smoothly as there is a limited number of forestry field staff. When the HKM agenda was being promoted intensively, a change in the forestry organization at the field level took place. Forestry matters in the regency were transferred to the Technical Implementing Unit Forest Management Unit, which is under the coordination of the provincial forestry office. This change resulted in a job transfer of the forestry

${ }^{19}$ Also see: Octavia, 2019

Maring (2022) 
technical staff to another autonomous institution such as district agriculture agency in the regency. The Forest Management Unit officers continued to provide understanding to the community about the ecological function of protected forests, identification of potential agroforestry, procedures for HKM permit, the community's rights and obligations, forest protection, and they encouraged cultivation activities in licensed HKM areas. According to multiple parties in the field, technically speaking, there are four priorities in the utilization of HKM areas, namely: First, cultivation by using an agroforestry model. Second, utilization of non-timber forest products (hasil hutan bukan kayu). Third, utilization of environmental services. Fourth, encouraging the community to plant/cultivate outside of the forest area as an attempt to alleviate pressure on the forest.

The current condition is given support by the village administration as some villagers do not own cultivation land outside of the forest area. The village government apparatus, proactively, reports the readiness of the community in the HKM program to the forestry technical implementing unit. In some villages, customary figures and village administrators actively raise their residents' awareness as the impact of illegal activities in the forest areas have resulted in drying springs in some villages. These illegal activities include deforestation and cultivation of potatoes (Solanum tuberosum), carrots (Daucus carota subsp. sativus), and other vegetable crops intensively, as witnessed in V3 and V5. The support of the village administration is also given by issuing a Village Regulation in certain villages to preserve their springs using the village budget allocation to develop nurseries for annuals. The village administration and community figures (key persons) urge the forestry institution to take control of illegal activities in the forest area. This is stated by LM, a community figure in V3 village:

"Forestry officials must take a firm stand and take action against the community who received the HKM permit for destroying the forest. If the HKM permit recipient acts to destroy the forest, it is better if the permit is revoked, rather than causing trouble for other communities due to flooding and draining springs around the village."

In relation to the prolonged conflict that occurred, the implementation of HKM is a significant achievement for improving the community's economy and sustaining the forest. The initiators of the program, namely the government, NGOs, and community figures, stated that the challenges they are currently facing in promoting the HKM program today are: First, convincing the community to perceive HKM as a long term and comfortable alternative choice through the 35 years permit mechanism. Second, ensuring the borders of the claimed community-managed areas on the field since reality on the ground specifies the forest area to be controlled by the community by cultivating annual and seasonal plants. Third, a persuasive approach is required of the forestry apparatus and NGOs to avoid horizontal conflict from recurring. Fourth, technical intervention is to be done carefully and by adapting to the agroforestry model, wherein industrial plants and CGPRT have been developed by the community. Fifth, maintaining the continuity of the social and technical processes in the implementation of HKM, from dissemination of information, mapping of HKM areas, detailed organization of land, to proportional distribution of lands. These social and technical processes are prerequisites in applying for a commercial utilization permit of HKM. Sixth, accommodating the local customary system in the process of mapping, planning, and 
implementation on the field. The community has their local wisdom concerning the management and protection of spring water area, cultivation areas (opidun kare taden), and protected areas in the forest area's core zone (opi dun kare dunan). Seventh, enforcing control, evaluation, and sanctions to group members violating HKM provisions. HKM group members proven to be negligent in carrying out their obligations and neglecting their land are to be reprimanded and given a sanction of land transfer to other members. ${ }^{20}$

\section{DISCUSSION}

The depiction of empirical reality on social forestry above indicates several key concepts underlying the analysis, namely conflict transformation, collaboration, communication of interests, and integrative policy. Social forestry is a social arena that is not free from conflict of interests among multiple parties, which, in the above case, were carried out through various schemes and agendas of struggle. In order to secure a long term conflict resolution and realize the public's interest as well as maintain forest sustainability, collaboration and conflict transformation approaches were required. Social forestry conflict transformation needed communication of interests and policy that integrated the various social movements and policy initiatives and urged realization through technical activities on the field. Concerning such perspective, there are three overarching themes to be discussed here.

\subsection{Significance of conflict transformation approach and multi-stakeholder collaboration}

The effort to promote the democratization of forest management through a multistakeholder approach to create equality among stakeholders was a vital phase in the land management conflict transformation. Facilitation in the implementation of the multi-stakeholder approach contributed in resolving the conflict that involved multiple parties, which included the community, the government, and NGOs. The process became complicated as each party deliberately built their basis of support in the community. The multi-stakeholder collaboration approach to unite the conflicting parties was done through various means such as joint trainings, joint comparative studies, negotiations among parties, formation of a conflict resolution working group, and establishment of a multi-stakeholder forestry forum. Aside from the support within the framework of the multi-stakeholder approach, multi-stakeholder forestry also provided direct support to the partners, i.e. forestry office, NGOs, and customary community groups in the area. These means were selected and carried out in the multistakeholder forestry program using a conflict transformation approach in order to provide as much space as possible for the stakeholders to articulate their interests and to continue their role in proportion (Elizabeth et al., 2007; Fahmi et al., 2003; Maring, 2010; Royo et al, 2010).

The conflict transformation approach opened up the conflict resolution process by providing a forum for all those involved in the conflict to articulate their interests. The conflicting parties were urged to reflect and learn together from all the incidents and conflict they were involved in. Through such a process, all parties were facilitated to be creative in finding ways of achieving long term and sustainable conflict resolution (Foundation, 2013; Lee et al., 2017). More broadly, conflict transformation was also

\footnotetext{
${ }^{20}$ Also see: ASFN, 2014; Octavia, 2019; Rosary, 2017; Yanto, 2017.
} 
considered as an opportunity for the community to create social change together. Conflict transformation was expected to reduce acts of violence, create opportunities for seeking out justice for all community members in each of their particular social structural settings. Accordingly, the idea of conflict transformation touches on issues of humanity. Regarding implementation in the field, the conflict transformation approach does not adhere to specific and rigid techniques and methods, but it is more responsive and dynamic to adapting with conditions in the field (Kane et al., 2018; Madden \& McQuinn, 2014; Maring, 2013; Putri, 2017).

The above illustration shows the importance of continuity in facilitation support provided by the government, NGOs, and donor organizations. The establishment of the vision to democratize forest management by using a multi-stakeholder approach in the conflict transformation phase was a significant achievement to set the foundation for developing social forestry (Fahmi et al., 2003; Royo et al., 2010). The qualitative achievement such as changing attitudes, accepting differences of opinion, and readiness to collaborate with other parties (between communities, government, and NGOs) in the conflict transformation phase since the early reform era opened up an entry point into the technical implementation phase. Integrative policy support and directed technical activities were responded through the collaboration between the NGOs and forestry apparatus in the field for transformation of role, technical capacity building for the community in terms of agro-product processing, reinforcement of social institutions, and market network for the community or farmers (Maring, 2020). It is observed that collaboration and conflict transformation approaches are important processes that lay the foundation for social forestry movement in the field (Markopoulos, 2012). Such processes require integrative policy support to direct and mobilize technical activities for implementing social forestry (Briassoulis, 2004; Herawati et al., 2017; Setiahadi et al., 2017).

\subsection{Communication of multi-stakeholder interests and multi-stakeholder facilitation support}

Conflict transformation requires open articulation of interests so that all parties can have a mutual understanding of their respective positions (Maring, 2010; Riggs et al., 2018). Empirical evidence indicates that articulation of interests takes time and it is no easy task. In the case above, each party involved were willing to meet, identify their interests, and negotiate, yet each of them maintained their respective positions. Presumptions from each side continued to occur driven by the vision of each of the organization's network and social status sentiments in the local context. NGOs at the local level were still influenced by movements at the national level. On the other hand, the regional government tried to implement government policy on HKM and maintain their authority over the state forest area. Such construction of interests required facilitation support from an independent party with the vision and purpose of promoting the democratization of forest management through multi-stakeholder approach, collaboration, and joint learning (Elizabeth et al., 2007; Fahmi et al., 2003; Maring, 2010; Royo et al, 2010). ${ }^{21}$

Intensive and open facilitation support had encouraged the parties involved to understand their respective interests. Various methods that were able to help in the

\footnotetext{
${ }^{21}$ Also see the report by Manembu and Saragih (2006) on: Impact Review of Multistakeholders Forestry Programme in Conflict of Natural Resources.
} 
process included a series of workshop on aligning perceptions, capacity building, exchange of joint learning, persuasive conflict resolution mediated by a conflict mediation team (consisting of academics, central forestry officials, and conflict mediator), and the establishment of a multi-stakeholder communication forum. Such methods were, consequently, able to alter their perspectives and provide alternative choices in resolving conflicts (Asmin et al., 2019; Pujo et al., 2018; Riggs et al., 2018). The multi-stakeholder forestry process, which had been built openly since the start of the reform era by involving the community, NGOs, the regional, provincial, and central governments, donor organizations, the CBFM Working Group, and conflict resolution facilitators, succeeded in constructing a common goal to protect the community's management rights in the forest area and to guarantee community welfare while establishing commitments for preserving the forest. In multistakeholder forestry processes, the construction of a common goal was an essential requirement in promoting collaboration (Essawi \& Tilchin, 2012; Maring, 2010; Suporahardjo, 2005).

The lengthy process above affirms the significance of inclusive collaboration for all sides. It is important to conduct inclusive collaboration as a process that runs in parallel with the idea and approach of conflict transformation. The classical view on conflict as an instrument of social change was not an appropriate choice, given alternative options for collaboration. The idea of conflict transformation was able to promote social change in a sustainable manner as all stakeholders participated in constructing the direction of change that all intended to achieve. The idea of conflict transformation is in line with the perspectives of dynamic power/authority, which suggests mutually shared roles to all the parties. Such perspectives of power/authority considers forest tenure conflicts as a result of unbalanced power relations among the relevant parties in forest tenure (Bodin, 2017; Dhungana et al., 2017; Evans et al., 2008; Maring, 2010; Ratner et al., 2017; Suporahardjo, 2005). Achieving a dynamic yet balanced set of power relations began with each party openly articulating their interests as a basis for collaboration, which was supported through the creation of a common goal, and consistently implemented through control mechanisms (Adu et al., 2015; Maring, 2013; Ratner et al., 2014; Sumanto, 2009).

\subsection{Policies that integrate and mobilize technical activities of social forestry}

Various sources suggest that the social forestry movement has transpired since the early 1970s in several countries. Even long before that period, communities in various locations have developed a traditional system based on local wisdom and adapted to their environment (Negi et al., 2018; Prayogi, 2020; Rout, 2018; Zakaria et al., 2018). When the state-based forest management system was criticized, an alternative choice in the form of community-based forest management developed expansively throughout Indonesia in various ways and concepts, which were supported by national and international networks alike. The inclusive movement constructed new insights, perspectives, strategies, and methods or procedures that multiple parties established as key references. The implication of the movement was that it caused discord and conflict among the parties in a number of places. Such situations require policy support to integrate various interests among stakeholders (Briassoulis, 2004). The Ministry of Forestry as a part of the social forestry movement from the beginning should have had the formal authority to create a policy for integrating the various initiatives across various stakeholders.

The regional and central government policies and political commitments were important aspects for mobilizing social forestry (Asmin et al., 2019). Political 
commitment and policy that contributed to mobilizing social forestry began with the establishment of the social forestry target areas and the reinforcement of social forestry mobilizing institutions. At the national level, a vital policy for social forestry was the establishment of target areas in the 2015-2019 Mid Term National Development Plan, which defined a total area commitment of reaching 12.7 million hectares. The policy seemed to call upon all parties to move toward the real target of struggle, which is to prepare a space for communities around the forest area to manage the land. All of the struggles of harmonizing visions that are abstract-conceptual in nature, must be confirmed in the field, i.e. realized through the community's socioeconomic interests and forest sustainability principles. The advent of an integrated social forestry policy is an important momentum to achieve harmony between the objectives of forest conservation and the improvement of the economy of the communities living around the forest. In order to achieve such goals, the community needs to be supported through technical capabilities to manage the forest. Enhancing the community's capacity was, thus, a crucial aspect in developing social forestry (Boedhihartono, 2017; Maring, 2020; Nuddin et al., 2019; Pujo et al., 2018; Santika et al., 2017). Achieving the target area of social forestry had to take into consideration the process of fair land distribution as there were many administrative weaknesses and economic interests maintained by local actors (Nurlia et al., 2020; Royer et al., 2018).

The ministerial level policy on social forestry and Working Group on the Acceleration of Social Forestry (Kelompok Kerja Percepatan Perhutanan Sosial) was a powerful factor that integrated and mobilized technical activities. The social forestry policy accommodated all pre-existing schemes and initiatives representing communitybased forest management. The prolonged conflict at the study location was a result of the stakeholders' attitudes in disputing social forestry schemes that had not been integrated. The concept of social forestry had long been fought for, but an umbrella policy was necessary to accommodate all initiatives so that it did not become a focus of debate. Conceptually, it is easy to understand social forestry and CBFM as a vision and concept that advocates community interests and forest sustainability. However, in terms of social movement strategy, the concept can be disputed in the interest of each party, as we have witnessed in the case presented herein. NGOs identified themselves as the drivers and initiators of community-based forest management while accusing HKM as overly influenced by government authority. Disputes with arguments and claims of authority (at the top level such as between the regional government and NGOs) could propel the stakeholders to become involved in a non-realistic conflict. While in fact, a non-realistic conflict is of no importance to the community who in reality were fighting for certainty of management rights over state forest area lands (Jackson, 1993; Rhodes, 2008).

\section{CONCLUSION}

This research drew from key concepts in concepts and policies of social forestry, conflict transformation, collaboration, communication of interests, and technical implementation activities to realize community interests and pursue aims of forest sustainability. Social forestry is a social arena that was not free from conflict of stakeholder interests, which were carried out through various arenas of conflict over time. In order to achieve longer term conflict resolution, however, collaboration and conflict transformation approaches were required to realize the mutual outcomes of supporting community interests and achieving forest sustainability. Conflict 
transformation of social forestry required communication of interests and policies that integrated and promoted technical activities in the field.

Latent and open social conflict that had occurred for decades involving the government, the community, and NGOs needed a fundamental resolution with longlasting impact. The social conflict that served as the backdrop of the social forestry arena was unavoidable because it forced stakeholders to follow interests of a competing stakeholders. The conflict resolution process by way of collaboration and conflict transformation opened up new perspectives to implement sustainable exchanges. The conflict transformation approach should start by opening up insights of each stakeholder to reflect and learn to see their experience with conflict openly and then try to find a long-term joint resolution.

Policy support is needed to accommodate dynamic social forestry initiatives and to encourage relevant stakeholders to focus on the main agenda of guaranteeing forest sustainability and community welfare. Policy support is also necessary to ensure a solid institutional basis for social forestry, to integrate and emphasize the process of implementing social forestry schemes, and to provide direction for technical achievements in social forestry. In a long-term conflict situation that extensively involves multiple stakeholders, facilitation support from an external party in the form of continuous transformative ideas is necessary. The facilitation support should be open and fair for all parties to move and build a common perception, to encourage a reflection process, capacity building, and sustainable forest management technical capacity building.

Competing interests: The authors declare that they have no competing interests.

Acknowledgments: I would like to express my gratitude to the Rector of Budi Luhur University; the Dean of the Faculty of Communication Science, Budi Luhur University; the Director of Research and Community Development, Budi Luhur University; Budi Luhur Cakti Foundation; that have supported me throughout the writing process and in finalizing this article. My sincere appreciation to the informants who have provided me data for the research. I would also like to convey my appreciation to the two anonymous reviewers who provided extensive comments.

\section{References}

Adu, I. N., Muah, P., Sanda, M., Sarfo, F., \& Box, E. P. O. (2015). The Role of Conflict Management in Improving Relationships at Work: The Moderating Effect of Communication University of Education, Winneba-Ghana, Faculty of Social Science, Department of Business University of Ghana Business School, Department of Or. Journal of Emerging Trends in Economics and Management Sciences (JETEMS), 6(6), 367-376.

Almalki, S. (2016). Integrating Quantitative and Qualitative Data in Mixed Methods Research-Challenges and Benefits. Journal of Education and Learning, 5(3), 288. https://doi.org/10.5539/jel.v5n3p288

Anonymous. (2020). BPS-Statistic of Sikka Regency 2020. Maumere: BPS-Statistic Sikka Regency.

Archibald, M. M., Radil, A. I., Zhang, X., \& Hanson, W. E. (2015). Current mixed methods practices in qualitative research: A content analysis of leading journals. International Journal of Qualitative Methods, 14(2), 5-33. https://doi.org/10.1177/160940691501400205

ASFN. (2014). Fasilitasi Pengembangan HKm Sikka Fase Awal: September 2012 - Maret 2014. Sikka Summary Brief. ASEAN Social Forestry Network. 
Ashri, M. (2019). Reconciliation of Humanitarian Law and Human Rights Law in Armed Conflict. Hasanuddin Law Review, 5(2), 209-219. doi: http://dx.doi.org/10.20956/halrev.v5i2.1348

Asmin, F., Darusman, D., Ichwandi, I., \& Suharjito, D. (2019). Mainstreaming communitybased forest management in west 61ndones: Social forestry arguments, support, and implementation. Forest and Society, 3(1), 77-96. https://doi.org/10.24259/fs.v3i1.4047

Awang, S. A. (2006). Perubahan Kebijakan Atas Kewenangan Kelola Lahan Hutan Indonesia. Retrieved from https://sanafriawang.staff.ugm.ac.id website: https://sanafriawang.staff.ugm.ac.id/perubahan-kebijakan-atas-kewenangankelola-lahan-hutan-indonesia.html

Bodin, Ö. (2017). Collaborative environmental governance: Achieving collective action in social-ecological systems. Science, 357(6352). https://doi.org/10.1126/science.aan1114

Boedhihartono, A. K. (2017). Can Community forests be compatible with biodiversity conservation in Indonesia? Land, 6(1), 1-17. https://doi.org/10.3390/land6010021

Bong, I. W., Moeliono, M., Wong, G. Y., \& Brockhaus, M. (2019). What is success? Gaps and trade-offs in assessing the performance of traditional social forestry systems in Indonesia. Forest and Society, 3(1), 1-21. https://doi.org/10.24259/fs.v3i1.5184

Briassoulis, H. (2004). Policy Integration for Complex Policy Problems: What, Why and How. Berlin Conference "Greening of Policies: Interlinkages and Policy Integration," (May), 1-30. Retrieved from http://www.geocities.ws/policy_making/en/publicpolicy/environmental_policy. pdf

Chaudhary, P., Chhetri, N. B., Dorman, B., Gegg, T., Rana, R. B., Shrestha, M., ... Thapa, S. (2015). Turning conflict into collaboration in managing commons: A case of Rupa lake watershed, Nepal. International Journal of the Commons, 9(2), 744771. https://doi.org/10.18352/ijc.561

Creswell, J. W. (2013). Qualitative inquiry and research design: choosing among five approach. Thousand Oaks, CA: Sage.

Das, C. R. (2015). Social Forestry in Odisha: An Extraordinary International Aided Initiative Towards Revival and Restoration of Forests. International Journal of Reserch and Development - A Manajement Review (IJRDMR), 4 (2), 28-49.

Dhungana, S. P., Satyal, P., Yadav, N. P., \& Bhattarai, B. (2017). Collaborative Forest Management in Nepal: Tenure, Governance and Contestations. Journal of Forest and Livelihood, 15(1), 27-42. https://doi.org/10.3126/jfl.v15i1.23084

Elizabeth, E., Yuliani, L., Tadjudin, D., Indriatmoko, Y., Munggoro, D. W., Gaban, F., Maulana, F., Adnan, H. (2007). Multistakeholders Forestry: Steps for Change. Bogor, Indonesia: Center for International Forestry Research (CIFOR).

Erbaugh, J. T. (2019). Responsibilization and social forestry in Indonesia. Forest Policy $\begin{array}{lll}\text { and Economics, } & 109 & \end{array}$ https://doi.org/10.1016/j.forpol.2019.102019

Essawi, M., \& Tilchin, O. (2012). Adaptive Collaboration Model for Organizational Change. American Journal of Industrial and Business Management, 02(04), 145152. https://doi.org/10.4236/ajibm.2012.24019

Evans, K., de Jong, W., \& Cronkleton, P. (2008). Future scenarios as a tool for 
collaboration in forest communities. Sapiens, 1(2). https://doi.org/10.5194/sapiens-1-97-2008

Fahmi, E., Zakaria, R. Y., Kartodihardjo, H., \& Wahono, F. (2003). Analysis of Multistakeholder Forestry Processes In Indonesia. 1(2003). Jakarta, Indonesia: Multistakeholder Forestry Programme.

Fisher, L. A., Kim, Y. S., Latifah, S., \& Makarom, M. (2017). Managing forest conflicts: Perspectives of Indonesia's forest management unit directors. Forest and Society, 1(1), 8-26. https://doi.org/10.24259/fs.v1i1.772

Fisher, M.R.; Moeliono, M.; Mulyana, A.; Yuliani, E.L.; Adriadi, A.; Kamaluddin; Judda, J; Sahide, M. A. K. (2018). Assessing the new social forestry project in Indonesia: recognition, livelihood and conservation? International Forestry Review, 20(3), 346-361. https://doi.org/https://doi.org/10.1505/146554818824063014

Fisher, M. R., Dhiaulhaq, A., \& Sahide, M. A. K. (2019). The politics, economies, and ecologies of 62ndonesia's third generation of social forestry: An introduction to the special section. Forest and Society, 3(1), 152-170. https://doi.org/10.24259/fs.v3i1.6348

Foundation, C. (2013). Approaches to Conflict Transformation: LESSONS FROM ALGERIA, DENMARK, EGYPT, KENYA, MOROCCO, TAJIKISTAN AND YEMEN. Retrieved from http://www.css.ethz.ch/publications/pdfs/Conflict_Transformation_in_Practice _2013.pdf

Hakim, I. (2010). Orientasi Makro Kebijakan Social Forestry di Indonesia pp 1-32 dalam: S. Anwar dan I. Hakim (Ed.). Menuju Restorasi Pembangunan Kehutanan Berkelanjutan.

Herawati, T., Liswanti, N., Banjade, M. B., Mwangi, E. (2017). Forest tenure reform implementation in Lampung province: From scenarios to action. Forest Tenure Reform Implementation in Lampung Province: From Scenarios to Action, 0-8. https://doi.org/10.17528/cifor/006418

Jackson, J. (1993). Realistic group conflict theory: a review and evaluation of the theoretical and empirical literature. The Psychological Record, 43(3), 395-413.

Kane, S., Dhiaulhaq, A., Sapkota, L. M., \& Gritten, D. (2018). Transforming forest landscape conflicts: The promises and perils of global forest management initiatives such as REDD+. Forest and Society, 2(1), 1-17. https://doi.org/10.24259/fs.v2i1.3203

Koning, D. R., Capistrano, D., Yasmi, Y., \& Cerutti, P. (2008). Forest-Related Conflict Impacts, Links, and Measures to Mitigate. Development, (January 2008).

KPA. (2020). Laporan konflik agraria di masa pandemi dan krisis ekonomi: Catatan akhir tahun 2020. Jakarta, Indonesia: Konsorsium Pembaruan Agraria (KPA).

Lee, Y., Rianti, I. P., \& Park, M. S. (2017). Measuring social capital in Indonesian community forest management. Forest Science and Technology, 13(3), 133-141. https://doi.org/10.1080/21580103.2017.1355335

Madden, F., \& McQuinn, B. (2014). Conservation's blind spot: The case for conflict transformation in wildlife conservation. Biological Conservation, 178(January 2015), 97-106. https://doi.org/10.1016/j.biocon.2014.07.015

Maring, P. (2010). Bagaimana kekuasaan bekerja di balik konflik, perlawanan, dan kolaborasi. Bekasi, Indonesia: Lembaga Pengkajian Antropologi Kekuasaan Indonesia.

Maring, P. (2013a). Kekuasaan yang Bekerja Melalui Perlawanan: Kasus Penguasaan 
Hutan oleh Masyarakat dan Perusahaan. Indonesian Journal of Social and Cultural Anthropology. July-December, Vol. 34 No. 2. https://doi.org/10.7454/ai.v34i2.3971

Maring, P. (2013). Transformasi Konflik Menuju Kolaborasi: Kasus Resolusi Konflik Penguasaan Hutan. INSANI, 1(14), 51-60.

Maring, P. (2015). Culture of Control versus the Culture of Resistance in the Case of Control of Forest. Makara Human Behavior Studies in Asia, 19 (1), 27-38. https://doi.org/10.7454/mssh.v19i1.3471

Maring, P. (2020). The strategy of shifting cultivators in West Kalimantan in adapting to the market economy: empirical evidence behind gaps in interdisciplinary communication. Journal of Political Ecology, 27(1), 1016-1035. https://doi.org/10.2458/V27|1.23757

Markopoulos, M. (2012). Collaboration and multi-stakeholder dialogue: A review of literature. (March). International Union for Conservation of Nature and Natural Resources.

Maryudi, A., Devkota, R. R., Schusser, C., Yufanyi, C., Salla, M., Aurenhammer, H., ... Krott, M. (2012). Back to basics: Considerations in evaluating the outcomes of community forestry. Forest Policy and Economics, 14(1), 1-5. doi: https://doi.org/10.1016/j.forpol.2011.07.017

Moeliono, M., Thuy, P. T., Bong, I. W., Wong, G. Y., \& Brockhaus, M. (2017). Social forestry-why and for whom? A comparison of policies in vietnam and Indonesia. Forest and Society, 1(2), 78-97. https://doi.org/10.24259/fs.v1i2.2484

Mohamad, M., Yubaidi, R., Hussein, S., Ismail, R., Isa, S., \& Abdul Aziz, S. (2021). Measuring the Low-Income Earner on Housing Access in Urban Areas of Indonesia and Malaysia. Hasanuddin Law Review, 7(2), 61-74. doi: http://dx.doi.org/10.20956/halrev.v7i2.2876

Morrill, C. and Rudes, D. S. (2010). Conflict Resolution in Organization. Article in Annual Review of Law and Social Science. Center for the Study of Law and Society, University of California, Berkeley.

Munggoro, D. W. (2002). Konflik Tak Kunjung Padam di Sikka. Jurnal Komuniti Forestri. Seri 6 Tahun V Desember 2002. Bogor, Indonesia: LATIN.

Nassaji, H. (2015). Qualitative and descriptive research: Data type versus data analysis. Language Teaching Research, 19(2), 129-132. https://doi.org/10.1177/1362168815572747

Negi, S., Pham, T. T., Karky, B., \& Garcia, C. (2018). Role of community and user attributes in collective action: Case study of community-based forest management in Nepal. Forests, 9(3), 1-20. https://doi.org/10.3390/f9030136

Nindyatmoko, A., Setyowati, K., \& Haryanti, R. H. (2020). Conflict Resolution in Community Governance Perspective: Social Capital Analysis on Land Tenure Conflict in Bebidas Village, Lombok. 510(Icosaps), 283-288. https://doi.org/10.2991/assehr.k.201219.043

Nuddin, A., Arsyad, M., Putera, M. I., Nuringsih, N., \& Teshome, T. T. (2019). Making the case for institutional support on designing agroforestry technology models for rehabilitating critical lands. Forest and Society, 3(1), 49-63. https://doi.org/10.24259/fs.v3i1.5975

Nurlia, A., Waluyo, E. A., \& Asmara, W. H. (2020). Land conflict resolution strategy in Solok Buntu Resort, Berbak-Sembilang National Park. IOP Conference Series: Earth and Environmental Science, 533(1). https://doi.org/10.1088/1755- 


\section{$1315 / 533 / 1 / 012020$}

Octavia, D. (2019). Puslitbang Hutan Perkuat Kerjasama Pengelolaan Hutan Berbasis Masyarakat di KPHL Sikka NTT. https://www.forda-mof.org/berita/post/6232puslitbang-hutan-perkuat-kerjasama-pengelolaan-hutan-berbasis-masyarakatdi-kphl-sikka-ntt.

Pambudi, A. S. (2020). The Development of Social Forestry in Indonesia: The Journal of Indonesia Sustainable Development Planning, 1(1), 57-66. https://doi.org/10.46456/jisdep.v1i1.11

Prayogi, R. (2020). Local wisdom of Bonai people in Ulak Patian, Riau. ETNOSIA : Jurnal Etnografi Indonesia, 5(1), 50 - 65. https://doi.org/10.31947/etnosia.v5i1.8953

Prihatin, P., \& Wicaksono, A. (2020). The Conflict in Indonesia's Forestry Sector: A Case Study of a Community Conflict with Company Industrial Plantation Forest (HTI) in Pelalawan Riau Province. 371-382. https://doi.org/10.4108/eai.25-102019.2300538

Pujo, Sofhani, T. F., Gunawan, B., \& Syamsudin, T. S. (2018). Community capacity building in social forestry development: A review. Journal of Regional and City Planning, 29(2), 113-126. https://doi.org/10.5614/jrcp.2018.29.2.3

Purnomo, E. P., \& Anand., P. . (2014). The Conflict of Forest Tenure and the Emergence of Community Based Forest Management in Indonesia. Journal of Government and Politics, 5(1), 20-31. https://doi.org/10.18196/jgp.2014.0003

Putri, F. J. (2017). Analysis of Conflict between the Society and Perhutani (Company of Indonesian Forestry ) As a Result of Taking Forestry Land. 7(7). https://doi.org/10.18178/ijssh.2017.7.7.870

Ratner, B. D., Mam, K., \& Halpern, G. (2014). Collaborating for resilience: Conflict, collective action, and transformation on Cambodia's Tonle Sap Lake. Ecology and Society, 19(3). https://doi.org/10.5751/ES-06400-190331

Ratner, B. D., Meinzen-Dick, R., Hellin, J., Mapedza, E., Unruh, J., Veening, W., ... Bruch, C. (2017). Addressing conflict through collective action in natural resource management. International Journal of the Commons, 11(2), 877-906. https://doi.org/10.18352/ijc.768

Ravindranath, N. H., Murali, K. S., \& Sudha, P. (2006). Community forestry initiatives in Southeast Asia: A review of ecological impacts. International Journal of Environment and Sustainable Development, 5(1), 1-11. https://doi.org/10.1504/IJESD.2006.008678

Rhodes, G. I. (2008). Conflict resolution and conflict transformation practice: is there a difference? Copyright 2008 Gloria Ileen Rhodes All Rights Reserved. George Mason University Fairfax, VA.

Riggs, R. A., Langston, J. D., Margules, C., Boedhihartono, A. K., Lim, H. S., Sari, D. A., ... Sayer, J. (2018). Governance challenges in an eastern Indonesian forest landscape. Sustainability $\quad$ (Switzerland), $10(1), \quad 18$. https://doi.org/10.3390/su10010169

Rosary, E. de. (2017). Program Hutan Kemasyarakatan, Bagaimana Perkembangannya di Kabupaten Sikka? https://www.mongabay.co.id

Rout, S. (2018). Sustaining Southeast Asia's Forests: Community, Institution and Forest Governance in Thailand. Millennial Asia, 9(2), 140-161. https://doi.org/10.1177/0976399618786298

Royer, S. De, Noordwijk, M. Van, \& Roshetko, J. M. (2018). Does community-based forest management in Indonesia devolve social justice or social costs? International 
Forestry

Review,

$20(2)$

$167-180$

https://doi.org/10.1505/146554818823767609

Royo, A. G., Hardiyanto, A., Alamsyah, Z., \& Hasanuddin, L. (2010). Multistakeholder Forestry Program - Milestones and Challenges. Jakarta, Indonesia: Royal Norwegian Embassy Jakarta.

Salam, M. A., Noguchi, T., \& Pothitan, R. (2006). Community forest management in Thailand: Current situation and dynamics in the context of sustainable development. New Forests, 31(2), 273-291. https://doi.org/10.1007/s11056005-7483-8

Santika, T., Meijaard, E., Budiharta, S., Law, E. A., Kusworo, A., Hutabarat, J. A., ... Wilson, K. A. (2017). Community forest management in Indonesia: Avoided deforestation in the context of anthropogenic and climate complexities. Global Environmental Change, 46(December 2016), 60-71. https://doi.org/10.1016/j.gloenvcha.2017.08.002

Scott, J.C. (1985). Weapon of the weak: everyday forms of peasant resistance. New Haven: Yale University Press.

Scott, J.C. (1992). Domination and the arts of resistance: hidden transcripts. New Haven: Yale University Press.

Setiahadi, R., Pratiwi, D., \& Ratnaningtyas, D. (2017). Deliberation process analysis of community based forest management policies implementation in Indonesia. International Journal on Advanced Science, Engineering and Information Technology, 7(3), 1076-1082. https://doi.org/10.18517/ijaseit.7.3.2127

Stern, M. J., \& Coleman, K. J. (2015). The Multidimensionality of Trust: Applications in Collaborative Natural Resource Management. Society and Natural Resources, 28(2), 117-132. https://doi.org/10.1080/08941920.2014.945062

Suhardjito, D., \& Wulandari, C. (2019). A reflection of social forestry in 2019: Towards inclusive and collaborative government approaches. Forest and Society, 3(1), 137-140. https://doi.org/10.24259/fs.v3i1.6099

Sumanto, S. E. (2009). Social Forestry Development Policy in Conflict Resolution Perspective. Forestry Policy Analysis Journal, 6, 13-25.

Suporahardjo. (2005). Strategi dan Praktek Kolaborasi: Sebuah Tinjauan. In Suporahardjo (Ed.), Manajemen Kolaborasi (Memahami Pluralisme Membangun Konsensus. Bogor, Indonesia: Pustaka Latin.

Tajuddin, T., Supratman, Salman, D., Yusran. (2019). Bridging sosial forstry and forest management units: Juxtaposing policy imaginaries with implementation practices in a case from Sulawesi. Forest and Society. Vol 3 (1): 97-113. April 2019.

Wahyu, Golar, Massiri, S. (2019). Analisis Kepentingan Stakeholders dalam Program Pemberdayaan Masyarakat di Hutan Desa Nano Kecamatan Kulawi. J. ForestSains 16 (2), Juni 2019.

Wang, N. and Wu, G. (2020). A Systematic Approach to Effective Conflict Management for Program. Journals.sagepub.com/home/sgo

Wulan, Y. C., Yasmin, Y., Purba, C., Wollenberg, E. ((2004). Analisis Konflik Kehutanan di Indonesia 1997-2003. Center for International Forestry Research.

Yanto, Y. (2017). Hutan Kemasyarakatan (HKM): Rekonsiliasi Konflik Menuju Pengelolaan Eko-Humanis. Maumere: Wahana Tani Mandiri (WTM).

Yeni, I., Agustarini, R., Heryati, Y. (2018). Stakeholders Analysis in the Collaboration on Non Timber Forest Product Development in Pasaman Barat Regeny. Jurnal 
Analisis Kebijakan Kehutanan Vol. 15 No. 2, Novemver 2018.

Zakaria, R. Y., \& et al. (2018). Naskah Akademik Reformulasi Kebijakan Perhutanan Sosial. In Academia.Edu. Retrieved from: http://www.academia.edu/download/56358312/Naskah_Akademik_Reformulas i_Kebijakan_PS_11012018.pdf 